Berkala Ilmu Perpustakaan dan Informasi, Vol. 17, No. 2, Desember 2021, Hal. 141-153 https://doi.org/10.22146/bip.v17i1.1491

ISSN 1693-7740 (Print), ISSN 2477-0361 (Online)

Tersedia online di https://journal.ugm.ac.id/v3/BIP

\title{
Perpustakaan dalam pelestarian warisan budaya di Indonesia tinjauan literatur sistematis
}

\author{
Septa $^{1}$, Tamara Adriani Salim ${ }^{2}$ \\ ${ }^{1,2}$ Departemen Ilmu Perpustakaan, Fakultas Ilmu Pengetahuan Budaya, \\ Universitas Indonesia, Depok, 16424, Indonesia \\ e-mail:septa@ui.ac.id
}

\section{Naskah diterima: 25 Maret 2021, direvisi: 18 Juni 2021, disetujui: 17 Juli 2021}

\begin{abstract}
ABSTRAK
Pendahuluan. Perpustakaan sebagai lembaga informasi bertugas dalam menghimpun, mengelola serta mendiseminasikan pengetahuan mempunyai peranan yang penting dalam melaksanakan pelestarian karya budaya bangsa.Salah satu bentuk peran tersebut yaitu dengan melestarikan warisan budaya. Penelitian ini bertujuan dalam menguraikan peran perpustakaan dalam melestarikan warisan budaya melalui publikasi artikel ilmiah dengan topik warisan budaya.

Metode penelitian. Pada penelitian ini menggunakan metode literatur sistematis dengan pendekatan kualitatif.

Data analisis. Metode pengumpulan dan analisis data yang digunakan terdiri dari beberapa tahapan dimulai dengan tahap perancangan, pelaksanaan, dan mensintesa terhadap hasil temuan pencarian.

Hasil dan Pembahasan. Temuan pada penelitian ini menunjukkan bahwa terdapat sekitar tujuh artikel jurnal terseleksi yang mengulas terkait kebijakan sebagai kendala dalam pelestarian warisan budaya. Selain itu terdapat lima artikel yang berisikan peranan perpustakaan yang berfokus pada wujud fisik dan edukasi masyarakat.

Kesimpulan. Berdasarkan keseluruhan artikel jurnal ilmiah terseleksi menjabarkan mengenai bentuk peranan perpustakaan yang ada di Indonesia dalam melestarikan warisan budaya yang berfokus pada kegiatan edukasi pada masyarakat, pengadaan, perawatan bangunan fisik, perawatan koleksi naskah kuno dan penambahan koleksi yang bertemakan kebudayaan, selanjutnya dijabarkan juga terkait kendala dan tantangan yang dihadapi oleh perpustakaan yaitu kebijakan yang berdampak pada minimnya SDM, anggaran dan sarana prasarana.
\end{abstract}

Kata kunci: library; preservation; culture heritage; literatur sistematis; Indonesia

\section{ABSTRACT}

Introduction. Libraries as information institution serves users by collecting, managing and disseminating information and knowledge. One of the important is by preserving cultural heritage. This study aims to describe role of libraries in preserving cultural heritage through publication of scientific articles on the topic of cultural heritage.

Data Collection Methods. The paper used a systematic literature review with a qualitative approach.

Data Analysis. Several stage involved in data analysis included planning, implementinging, and synthesising the search results

Results and Discussion. Findings indicate there are seven selected journal articles discussing policies as obstacles in the preservation of cultural heritage and there are five articles containing the role of libraries focusing on physical form and public education.

Conclusion. Based on the selected scientific journal articles describing the role of libraries in Indonesia in preserving cultural heritage, the topics focuses on education for community, procurement, maintenance of physical buildings, ancient manuscripts collections and cultural themes. Furthermore,constraints and challenges faced by libraries, including policies, create an impact on human resources, budget and infrastructure.

Keywords: library; preservation; culture heritage; sysatic literature; Indonesia 


\section{A. PENDAHULUAN}

Wilayah Indonesia yang sangat luas dari sabang ke Merauke berdampak pada dikenalnya negara Indonesia yang memiliki kekayaan akan sumber daya alam yang berlimpah dan juga kekayaan budaya yang sangat beragam. Kekayaan budaya dan sumber daya alam ini diperoleh dari beragamnya suku bangsa, etnis dan ras yang menempati berbagai daerah di nusantara pada zaman dahulu. Pada tiap-tiap daerah di Indonesia mempunyai ragam dan ciri khasnya tersendiri diberbagai aspek, termasuk pada aspek kebudayaan. Walaupun aspek kebudayaan pada tiap daerah di Indonesia terkadang hampir sama, namun jika lebih dicermati suatu bentuk kebudayaan yang berasal dari daerah satu dan yang lain memiliki keunikannya sendiri. Berangkat dari keunikan inilah yang mencerminkan kekhasan tradisi dan budaya dari masing-masing daerah yang menghasilkannya.

Sejarah, tradisi dan artefak budaya dihasilkan oleh keunikan dan kekhasan budaya pada masing-masing daerah di Indonesia yang sebelumnya pada zaman dahulu diterapkan oleh nenek moyang kemudian diturunkan dari zaman nenek moyang hingga sampai pada generasi milenial saat ini. Sejak tahun 2009 sampai 2017, terdapat kurang lebih 7782 karya budaya Indonesia yang ditetapkan dan tercatat sebagai warisan budaya tak benda atau intangible cultural heritage (Kemendikbud, 2017). Penetapan dan pencatatan karya budaya Indonesia ini oleh pemerintah bertujuan untuk menjaga, melestarikan serta melindungi warisan budaya tak benda yang berada di wilayah Negara Kesatuan Republik Indonesia (NKRI).

Namun, kekayaan budaya Indonesia yang berlimpah memicu banyaknya karya budaya yang hampir punah. Riset ini sebelumnya telah dilakukan oleh Lembaga Ilmu Pengetahuan Indonesia (LIPI) tahun 2016, dilansir pada laman Kompas, pada Rabu (24/5/2016) yang memaparkan bahwa hasil riset yang menunjukan bahwa terdapat 139 bahasa daerah/etnis di Indonesia yang kemungkinan akan segera punah. Hilang dan diklaimnya warisan budaya oleh pihak asing menjadi salah satu tugas bagi perpustakaan, karena Perpustakaan merupakan lembaga documenter yang memiliki tugas dalam mengelola berbagai jenis dokumen, salah satunya warisan budaya, disamping itu perpustakaan juga memiliki fungsi dalam melestarikan koleksi local content.

Penelitian mengenai peranan perpustakaan dalam melestarikan warisan budaya terdahulu lebih banyak memfokuskan kajian pada bentuk warisan budaya yang harus dilestarikan. Rahayu (2019) memfokuskan pada naskah Nagarakretagama, naskah Babad Diponegoro, arsip Konferensi Asia Afrika dan arsip VOC, Irfaniah (2020) memfokuskan pada pengetahuan tradisional sementara Yenianti (2018) memfokuskan pada naskah kuno. Penelitian-penelitian tersebut merupakan penelitian studi literatur. Sehingga beranjak dari hal tersebut belum banyak penelitian yang membahas terkait peran penting perpustakaan dalam melestarikan warisan budaya serta kendala atau tantangan yang dihadapi. Meskipun secara teori bahwa perpustakaan berperan penting dalam melestarikan warisan budaya, namun tidak banyak penelitian yang menunjukan secara explisit peran perpustakaan serta kendala atau tantangannya dalam pelestarian warisan budaya.

Penelitian mengenai peranan perpustakaan dalam melestarikan warisan budaya telah banyak dilakukan, tetapi terbatas pada cakupannya. Namun, pada penelitian ini mencakup semua jenis perpustakaan dan seluruh wilayah Indonesia. Penelitian mengenai peran perpustakaan dalam melestarikan warisan budaya dianggap relevan, dengan menggunakan pendekatan tinjauan literatur sistematis, sehingga penelitian ini dapat dijadikan bahan acuan atau reference dan masukan bagi penelitian lain dikemudian hari. Pada penelitian ini juga akan menguraikan peran perpustakaan dalam melestarikan warisan budaya melalui publikasi artikel ilmiah dengan topik warisan budaya.

\section{B. TINJAUAN PUSTAKA}

Pelestarian Warisan Budaya

Dalam kajian ilmu dokumentasi terdapat suatu konsep konvergensi dari ketiga lembaga 
dokumenter yaitu Libraries, Archive and Museum (LAM). Pada masing-masing lembaga dokumenter tersebut mempunyai sesuatu dan hal yang serupa yaitu "koleksi". Ketiga lembaga tersebut juga menyebutkan istilah serupa untuk memvisualkan jenis koleksinya, seperti "koleksi referensi", "koleksi arsip" dan "koleksi artefak". Semua jenis koleksi tersebut dinamakan "dokumen" dalam artian yang baru.

Perpustakaan merupakan lembaga informasi yang bertugas dalam mengelola semua jenis koleksi baik itu koleksi buku, catatan ataupun salinan secara professional dengan sistem yang terintegrasi guna memenuhi kebutuhan penelitian, pendidikan, informasi, pelestarian serta rekreasi bagi pemustakanya (UU No. 43 tahun 2007). Jenis koleksi "buku, salinan dan / atau catatan" juga dinamakan dengan istilah dokumen. Lembaga dokumenter yang salah satunya adalah perpustakaan, harus senantiasa beradaptasi dengan perkembangan terkait konsep dokumentasi baru saat ini. Konsep dokumentasi baru ini memicu perpustakaan untuk terus mengelola semua jenis dokumen termasuk salah satunya warisan budaya. Karena pada kajian ilmu dokuemtasi (Turner, 2015) menyebutkan bahwa perpustakaan memiliki studi baru dalam mengembangkan koleksinya yaitu dengan melakukan pengelolaan dokumen berupa warisan budaya.

Pelestarian warisan budaya merupakan suatu upaya dalam menjaga nilai seni dari bentuk karya budaya yang memiliki tujuan untuk menumbuhkan nilai tradisional, sehingga dalam pelaksanaan pelestarian budaya disesuaikan pada suatu kondisi dan situasi yang selalu berubah dan berkembang (Ranjabar, 2016). Jenis-jenis perpustaakaan baik itu perpustakaan khusus, perguruan tinggi, sekolah dan umum memiliki tugas dan fungsi kultural, hal ini dimaksudkan perpustakaan dituntut untuk senantiasa menjaga serta melestarikan warisan budaya atau local content. Dengan penyediaan akses koleksi yang memudahkan pemustaka sejalan peran perpustakaan pada bidang penelitian serta kekuatan institusional atau fokus kurikuler. Perpustakaan memiliki berbagai cara dalam memenuhi kebutuhan informasi pemustaka, salah satunya dengan menggabungkan sumber informasi dalam berbagai bentuk format sehingga dapat memudahkan akses baik secara fisik maupun virtual oleh pemustaka. Perpustakaan turut mengembangkan serta membangun akses koleksi ke bentuk bahan yang unik, salah satunya koleksi digital. Selain itu perpustakaan memiliki peran dalam menghimpun, mengelola, mendiseminasi serta melestarikan koleksi yang dibutuhkan oleh pemustaka, termasuk didalamnya koleksi tentang kebudayaan.

Koleksi budaya ini mempunyai arti penting sebagai (1) suatu informasi yang dapat mencerminkan unsur-unsur yang membangun dan membentuk kebudayaan terhadap suatu bangsa atau masyarakat. (2) berfungsi sebagai sumber ilmu pengetahuan, kebudayaan merupakan output dari hasil kegiatan dan aktivitas rasa, cipta dan karsa manusia sehingga memunculkan suatu pengetahuan yang dapat dimanfaatkan serta diperbaharui. (3) koleksi kebudayaan ini juga dapat menjadi sumber nilai moral atau kearifan karena memuat ajaranajaran tentang cara berhubungan dengan masyarakat, menjalin hubungan dengan alam sekitar, serta memaknai kehidupan. (4) dapat bernilai ekonomis dan membangun pariwisata, karena kebudayaan mempunyai unsur-unsur keindahan atau estetika serta kekhasannya tersendiri sehingga hal itu data dipertontonkan dengan dikemas dan ditampilkan secara menarik, kemudian dapat dinikmati oleh orang lain sehingga dapat diperoleh keuntungan, sejalan dengan hal itu dapat juga mengenalkan suatu bentuk tradisi dan budaya oleh daerah tertentu.

\section{METODE PENELITIAN}

Pada penelitian ini menggunakan metode tinjauan literatur sistematis (systematic literature review) dengan pendekatan kualitatif. Adapun metode systematic literature review merupakan suatu metode yang dilakukan dengan cara mengidentifikasi, mengintrepretasi serta mengevaluasi terhadap semua hasil riset atau penelitian yang relevan dengan research question serta topik fenomen tertentu yang 
menjadi fokus perhatian oleh peneliti (Triandini et al., 2019).

Adapun langkah-langkah dalam pengumpulan data dengan sistematika review (Perry \& Hammond, 2011) yaitu pertama dengan merumuskan pertanyaan penelitian, kedua mencari literature untuk tinjauan sistematis, ketiga menskrining dan menyeleksi artikel penelitian yang sesuai dan relevan, keempat menganalisis dan mensintesis terhadap temuan-temuan artikel kualitatif tersebut, lalu kelima dengan memberlakukan kendali mutu terhadap temuan yang telah diperoleh dan langkah terakhir keenam dengan menyusun atau membuat laporan.

\section{Menyusun Research Question}

Dalam menyusun pertanyaan mengacu pada pendekatan PICOC (Population, Intervention, Comparison, Outcomes, Context) (Wohlin et al., 2012). Dengan kriteria Populationnya mencakup pelestarian warisan budaya oleh perpustakaan, kriteria dalam Intervention mencakup pada batasan mengenai tantangan atau kendala dalam melaksanakan pelestarian warisan budaya, untuk kriteria Comparison cakupannya tidak ditemukan, kemudian pada kriteria Outcomes mencakup pada pelaksanaan pelestarian terhadap warisan budaya dan tantangan atau kendala dalam proses pelaksanaan warisan budaya di Indonesia dan terakhir yaitu Context berisi cakupan ulasan dari hasil identifikasi penelusuran pelaksanaan pelestarian warisan budaya.

Sehingga mengacu pada uraian tersebut, dihasilkan pertanyaan penelitian sebagai berikut:

R1: Berapa jumlah penelitian yang digunakan pada peran perpustakaan dalam melaksanakan pelestarian warisan budaya di Indonesia?

R2: Bagaimana tantangan atau kendala dalam melaksanakan pelestarian warisan budaya oleh perpustakaan di Indonesia?

R3: Bagaimana bentuk peranan atau upaya yang dilakukan perpustakaan dalam melestarikan warisan budaya di Indonesia?

\section{Strategi Penelusuran}

Tahapan pelaksanaan pada penelitian ini mengacu pada pendekatan pada item terhadap pelaporan pilihan untuk tinjauan dan analisis meta atau disebut prisma yang merupakan strategi dalam penelusuran artikel yang ditunjukkan dengan melalui istilah penelusuran, sumber data dan informasi dari database secara online, penggunaan kriteria inklusi dan eksklusi serta penilaian hasil pencarian dengan menjelaskan hasil penelusuran data yang telah diperoleh (Handayani, 2017).

\section{Istilah Penelusuran}

Pada istilah penelusuran ini merupakan suatu integrasi dan kombinasi dari beberapa kosata kata yang mempunyai kesamaan atau sinonim dengan menerapkan pada penggunaan metode penelusuran Boolean yaitu AND, OR, dan NOT. Dengan kriteria population pada integrasi sinonimnya yaitu peran perpustakaan dalam pelestarian warisan budaya OR pelestarian warisan budaya oleh perpustakaan, dalam intervention mencakup kriteria sinonim pelestarian warisan budaya OR upaya pelestarian warisan budaya AND tantangan dalam pelaksanaan pelestarian warisan budaya AND kendala pelestarian warisan budaya dan kriteria method terdapat integrasi sinonim Pelaksanaan OR tantangan OR kendala.

\section{Sumber Literatur dan Kriteria Inklusi dan Eksklusi}

Penelitian ini hanya menggunakan satu jenis database atau pangkalan data yaitu: Google Scholar. Database ini digunakan dalam menelusur artikel-artikel penelitian yang mencakup peran perpustakaan dalam melaksanakan pelestarian warisan budaya di Indonesia. Pemilihan database ini dikarenakan banyak tersedia artikel jurnal yang open access. Selanjutnya dalam penelitian ini ditentukan batasan istilah yang diterapkan dalam penelitian yang mana publikasi ilmiah selama 5 tahun terakhir dari tahun 2015-2020 terhitung saat penelitian dilaksanakan.

Adapun kriteria inklusinya yaitu artikel jurnal ilmiah yang dipublikasikan menggunakan Bahasa Indonesia, artikel jurnal 
ilmiah yang diterbitkan dari tahun 2015-2020 atau 5 tahun terakhir dan artikel jurnal ilmiah yang berfokus pada pelaksanaan pelestarian warisan budaya, baik itu peranan terkait upaya atau usaha dan tantangan atau kendala, serta kebijakan dari perpustakaan dan kriteria inklusinya berupa artikel jurnal ilmiah yang dipublikasikan dengan Bahasa Asing selain Bahasa Indonesia, artikel jurnal ilmiah yang diterbitkan sebelum ataupun sesudah tahun 2015-2020, serta artikel jurnal ilmiah yang tidak relevan dan sesuai dengan cakupan bahasan topik penelitian.

Dalam pengendalian kualitas hasil pencarian mempunyai tujuan dalam mengevaluasi kualitas dari artikel jurnal ilmiah dan manfaat temuan yang telah diperoleh. Pada uraian berikut terdapat pertanyaan yang membantu dalam menilai kualitas hasil pencarian dan temuan. Pada setiap pertanyaan tersebut mempunyai tiga alternative jawaban dengan nilainya masing-masing, yaitu jawaban Ya bernilai 1; Ragu-ragu bernilai 0.5; Tidak bernilai (Adrian et al., 2016).

Adapun pertanyaannya 1. Apakah dalam artikel jurnal ilmiah ini mendeskripsikan secara jelas tujuan dan maksud penelitian dilakukan? 2. Apakah penelitian ini terdapat deskripsi yang jelas mengenai metode penelitian yang digunakan? 3. Apakah penelitian ini menjelaskan peran atau upaya perpustakaan dalam pelestarian warisan budaya secara detail? Dengan keseluruhan pertanyaan disertai dengan jawaban Ya/ Ragu-Ragu/ Tidak.

\section{HASILDAN PEMBAHASAN}

Berdasarkan strategi penelusuran pada database jurnal ilmiah Google Scholar sebanyak 18 artikel jurnal ilmiah ditemukan. Namun setelah dilakukan tahapan seleksi, 2 artikel tidak bisa diakses secara full text dan 4 artikel jurnal lain termasuk eksklusi berdasarkan konteks pembahasan artikel jurnal yang dianggap tidak sesuai dengan fokus penelitian. Dengan demikian total artikel jurnal ilmiah yang akan direview dalam penelitian ini sebanyak 12 artikel jurnal, seperti terlihat pada gambar 1 .

Dengan berdasarkan pada data yang terhimpun dan dilaksanakan pada penilaian kualitas hasil pencarian berdasarkan beberapa kriteria yang telah ditentukan, hasil penilaian menunjukan nilai terendah 1,5 ( 2 artikel), nilai 2 (1 artikel), nilai 2,5 (2 artikel) dan nilai tertinggi 3 (7 artikel), lihat pada gambar 2 .

\section{R1: Berapa jumlah penelitian yang digunakan pada peran perpustakaan dalam melaksanaan pelestarian warisan budaya di Indonesia?}

Berdasarkan tahapan seleksi pada temuan artikel jurnal ilmiah, maka artikel jurnal ilmiah telah diseleksi dan digunakan pada peran perpustakaan dalam melestarikan warisan budaya terdapat 12 artikel jurnal ilmiah serta keseluruhan artikel ini menggunakan pendekatan secara kualitatif. Adapun metode pengumpulan data yang digunakan dalam artikel jurnal ilmiah tersebut yaitu melalui wawancara, observasi, studi literatur dan dokumentasi. Sebanyak 1 artikel melalui metode pengumpulan data studi literatur dan sisanya 11 artikel menggunakan metode pengumpulan data yaitu wawancara, observasi lapangan dan dokumentasi. Dengan distribusi tahun pada temuan artikel jurnal ilmiah yang digunakan dalam penelitian yaitu selama 5 tahun terakhir dari 2015-2020. Hasil temuan menghasilkan 1 artikel jurnal ilmiah yang diterbitkan tahun 2015 yaitu A4, artikel jurnal ilmiah yang diterbitkan tahun 2016 terdapat 1 artikel yaitu $\mathrm{A} 1$, artikel jurnal ilmiah yang diterbitkan tahun 2017 sebanyak 3 artikel yang masing-masing A2, A5, A9. Terbit tahun 2018 sebanyak 3 artikel yang masing-masing A6, A10 dan A12. Artikel jurnal yang terbit tahun 2019 sebanyak 3 artikel yaitu masing-masing A3, A8 dan S11 serta tahun 2020 sebanyak 1 artikel yaitu A7, seperti terlihat pada gambar 3 .

\section{R2: Bagaimana tantangan atau kendala dalam melaksanakan pelestarian warisan budaya oleh perpustakaan di Indonesia?}

Berdasarkan hasil ulasan dari temuan artikel jurnal ilmiah yang digunakan pada penelitian ini, maka dapat diketahui bahwa tantangan atau kendala dalam melaksanakan pelestarian warisan budaya oleh perpustakaan yaitu kebijakan, SDM, sarana, anggaran, 
kurangnya kesadaran masyarakat. Sebanyak 7 artikel diantaranya (A1, A2, A3,A6, A7,A8, A12) yang memiliki kendala dalam hal kebijakan, 5 artikel yang memiliki kendala dalam hal Sumber Daya Manusia (SDM) diantaranya (A6, A8, A9, A11, A12), 3 artikel yang terkendala dengan anggaran yaitu (A9, A9, A11), serta yang memiliki kendala dalam anggaran atau pembiayaan ada 2 artikel yaitu (A4 dan A9), seperti terlihat pada gambar 4.

\section{R3: Bagaimana bentuk peranan atau upaya yang dilakukan perpustakaan dalam melestarikan warisan budaya di Indonesia?}

Berdasarkan hasil ulasan dari temuan artikel jurnal ilmiah terseleksi, maka ditemukan beberapa bentuk peranan yang dilakukan perpustakaan dalam melestarikan warisan budaya yaitu dengan pengadaan koleksi melalui pembelian, baik itu hadiah maupun terbitan sendiri (A3, A6, A7, A8), dengan perawatan fisik bangunan (A1 dan A9), dengan memberikan edukasi serta menanamakan rasa cinta pada budaya untuk meningkatkan jati diri dan karakter yang cinta akan tanah air dan budaya (A1, A2, A5, A6, A11), kemudian dengan konservasi antara lain fumigasi, digitalisasi dan laminasi (A2, A4, A10, A12), seperti terlihat pada gambar 5 .

\section{Pembahasan}

Perpustakaan sebagai lembaga informasi yang bertugas dalam menghimpun, mengelola serta mendiseminasikan pengetahuan mempunyai peranan yang penting dalam melaksanakan pelestarian karya budaya bangsa dan salah satu bentuk peranan tersebut yaitu dengan melestarikan warisan budaya. Warisan dokumenter atau yang biasa dikenal dengan warisan budaya merupakan suatu ingatan kolektif dari suatu bangsa dan daerah yang berfungsi sebagai sumber pengetahuan dan pembelajaran, sehingga perlu untuk dilestarikan dan didiseminasikan kepada masyarakat luas, warisan budaya sangat penting untuk dipreservasi agar dapat dijadikan sebagai suatu acuan dan landasan dalam proses mengembangkan suatu bangsa dan negara terutama Negara Kesatuan Republik Indonesia
(NKRI) (Rahayu, 2019).

Dalam resolusi yang diadopsi oleh sidang umum Perserikatan Bangsa-Bangsa tugas terbesar yang harus dilakukan oleh UNESCO diantaranya dengan membuat otoritas publik, sector swasta dan masyarakat sipil yang mana secara keseluruhan masyarakat harus menyadari bahwa warisan budaya bukan hanya sebagai sebuah instrumen untuk perdamaian dan rekonsiliasi, tetapi juga sebagai faktor perkembangan. Pelestarian warisan budaya telah mendorong dalam menciptakan lapangan pekerjaan bagi penduduk lokal, melalui kerajinan tangan, wisata, dan munculnya perdagangan atau kegiatan baru. Secara umum diakui bahwa abad ke-21 akan menjadi abad globalisasi. Terlepas dari semua manfaat globalisasi ekonomi, menyebabkan ancaman substantif globalisasi budaya (Grazuleviciute, 2011). Kebudayaan merupakan penggerak penting dalam proses pembangunan ekonomi perkotaan.

Saat ini, pelestarian warisan budaya sejarah menjadi semakin penting. Melindungi warisan budaya bersifat ekonomis, historis, dan juga proses budaya. Warisan budaya tidak hanya bekas sejarah, tetapi juga salah satu identitas utama suatu bangsa. Sebagai sumber daya kunci, warisan budaya telah menjadi sebuah pendorong pembangunan berkelanjutan, untuk itu perpustakaan dapat memainkan peran dalam pelestarian warisan budaya ini. Warisan budaya dapat dikelola dan dilestarikan melalui beberapa cara. Salah satu cara yang umum digunakan adalah melestarikan warisan budaya melalui industri kreatif. Industri kreatif budaya adalah salah satu industri kreatif. Industri kreatif menjadi komponen penting berbasis pengetahuan pasca industri modern ekonomi (Hani et al., 2013). Tidak hanya dianggap bertanggung jawab atas pertumbuhan dan penciptaan lapangan kerja yang lebih tinggi dari rata-rata, warisan budaya juga kendaraan identitas budaya yang memainkan peran penting dalam memelihara keanekaragaman budaya (Songjie \& Xinghua, 2011). Oleh karena itu, masyarakat harus terlibat aktif dalam pelestarian warisan budaya ini dan perpustakaan harus dapat meningkatkan warisan 
kemanusiaan ini dengan melalui peningkatan kesadaran public dan peningkatan mobilitas serta tindakan-tindakan yang mana dapat mendukung nilai-nilai warisan budaya, terutama dengan melibatkan generasi muda khususnya. Oleh karena itu, sangat penting untuk mengaitkan warisan budaya dengan kebijakan atau regulasi pembangunan dan pentingnya menunjukkan suatu simbol kuat identitas rakyat ini dapat menjadi faktor pemersatu untuk rekonsiliasi nasional-yang mengartikan bahwa warisan budaya direvitalisasi dalam pikiran orang tidak hanya sebagai tanda dari masa lalu yang diakui bersama, tetapi juga sebagai fondasi dari masa depan bersama.

Pelaksanaan pelestarian warisan budaya bertujuan dalam menguatkan suatu budaya bangsa atau dikenal dengan revitalisasi budaya. Terkait revitalisasi budaya ini seorang ahli budaya (Alwasilah, 2016) berpendapat bahwa terdapat 3 tahap dalam proses pelaksanaannya yaitu pertama dengan menanamkan pemahaman yang bertujuan untuk menimbulkan kesadaran dalam diri masyarakat terkait dengan karya budaya yang dimiliki, kedua dengan merencanakan kegiatan untuk penguatan budaya secara kolektif agar dapat mencapai tujuan yang sama dengan hasil yang sama pula, kemudian terakhir ketiga dengan membangkitan kreatifitas kebudayaan, melalui inovasi dan modifikasi terhadap karya budaya yang dimiliki. Maka dari itu, istilah pelestarian merupakan usaha atau upaya yang berdasar yang disertai dengan beberapa faktor yang mendukungnya baik itu faktor internal maupun eksternal dari konteks yang akan dilestarikan, sehingga proses pelaksanaan pelestarian warisan budaya ini harus dapat mengenal teknik dan strategi yang digunakan serta didasarkan pada kebutuhan dan kondisinya masing-masing (Ranjabar, 2016). Sejalan dengan itu (Vassilakaki et al., 2019) menyatakan bahwa preservasi warisan budaya diartikan sebagai sebuah "panggilan dan praktik pengelolaan terhadap bentuk warisan budaya" yang merupakan cabang ilmu dari manajemen sumber daya budaya, meskipun preservasi warisan budaya mengacu pada praktik konservasi budaya, restorasi, arkeologi, sejarah dan arsitektur namun dalam melaksanakan praktik ini perpustakaan dimungkinkan dapat melalui pengembangan dan adopsi terhadap teknologi informasi dan komunikasi (TIK), yang dikembangkan untuk menekankan peranan komunikasi secara terpadu dan integrasi telekomunikasi serta perangkat lunak perpustakaan yang memungkinkan pengguna untuk mengakses, menyimpan serta memodifikasi informasi sumber daya budaya tersebut.

Pelaksanaan pelestarian warisan budaya merupakan salah satu konstribusi untuk mengembangkan, membangun serta menghidupkan sejarah dan budaya bangsa sebagai suatu bagian dari memahami peradaban suatu bangsa dan Negara. Wujud budaya bangsa yang masih tersedia serta dapat masyarakat saat ini lihat dan manfaatkan merupakan suatu hasil dari adanya upaya dari konstribusi pihak-pihak terkait untuk membangun dan menghidupkan kembali khazanah budaya dan peradaban yang dimiliki oleh bangsa dan negaranya. Dalam Undang-Undang Republik Indonesia No 43 Tahun 2007 tentang Perpustakaan pasal 21 ayat $3 \mathrm{~b}$ tertulis bahwa semua jenis perpustakaan baik umum, khusus, perguruan tinggi, sekolah dan nasional memiliki tugas dan tanggungjawab dalam membangun koleksi yang dimiliki secara nasional sebagai upaya untuk melestarikan hasil karya budaya bangsa dan negara.

Salah satu temuan dari artikel jurnal ilmiah terseleksi menunjukkan perannya dalam melestarian warisan budaya bangsa dengan melalui dan pelestarian naskah lontar (Saputri, 2018), terdapat 5 tahapan dalam proses konservasi naskah lontar yaitu Pencegahan kerusakan, konsolidasi, pemulihan, dan reproduksi (Wirayati, 2011). Tahapan pertama dengan pencegahan kerusakan naskah lontar merupakan tindakan preventif yang bertujuan untuk melindungi wujud budaya berupa benda degan cara mengendalikan kerusakan dan kondisi dari lingkungan sekitar serta disertai dengan cara menanganinya. Kedua dengan pelestarian yang dilakukan dengan cara menangani secara langsung benda budaya yang mengalami kerusakan karena diakibatkan oleh 
kerusakan lingkungan seperti faktor kimia, udara yang lembab, serta adanya serangga dan mikro organisme. Faktor-faktor kerusakan ini harus dihindari untuk mencegah kerusakan kembali dikemudian hari. Kemudian ketiga dengan konsolidasi yaitu dengan memperkuat bahan yang telah rapuh dengan memberikan perekat atau dapat dengan menggunakan bahan penguat lain. Keempat dengan restorasi yaitu memperbaiki benda budaya yang telah rusak dengan mengganti bagian yang rusak atau hilang agar bentukannya dapat mendekati seperti keadaan semula. Terakhir tahapan kelima reproduksi dengan cara menggandakan dari bahan yang asli, termasuk dengan bentuk mikro dan foto repronya serta dengan transformasi ke dalam bentuk digital.

Salah satu temuan dari artikel jurnal ilmiah terseleksi juga melaksanakan pelestarian warisan budaya dengan cara melestarikan batik dengan melalui perpustakaannya yang senantiasa melakukan pengadaan koleksi melalui pembelian, hadiah, dan terbitan sendiri yang bertemakan batik (De Carlo, 2019). Kemudian pada artikel jurnal ilmiah terseleksi juga menyebutkan kegiatan dalam pelestarian warisan budaya dilakukan dengan langkah perawatan bangunan fisik seperti perawatan cagar budaya, selanjutnya artikel jurnal terseleksi lainnya menjelaskan peran perpustakaan dalam memberikan edukasi kepada masyarakat akan pentingnya pelestarian suatu warisan budaya Indonesia yaitu salah duanya dengan melalui kegiatan seminar atau workshop mengenai isu-isu kebudayaan, dalam melaksanakan pelestarian warisan budaya ini menurut (Anggawira \& Mayesti, 2020) seorang pustakawan harus dapat berperan menjadi seorang konsultan informasi, spesialis teknologi serta manager pengetahuan yang mana pustakawan yang merupakan subjek dalam promotor komunikasi ilmiah harus dapat menyebarkan informasi serta mengedukasi masyarakat terutama terkait pelestarian warisan budaya. Dalam pelaksanaan preservasi warisan budaya terutama di Indonesia sangat penting untuk pustakawan dalam mengembangkan keterampilan yang mereka miliki sebagai tujuan untuk dapat membantu para professional informasi lain dalam mengambil proyek warisan budaya internasional dalam cakupan atau skala yang lebih besar. Dalam pelaksanaan warisan budaya yang terpenting adalah saling bekerja sama dengan erat serta kolaboratif dengan peneliti dan disiplin ilmu yang lain dan hal ini akan memungkinkan pustakawan untuk berkomunikasi dengan orang lain dengan berbagai bahasa yang sama dengan rekan sejawat atau tim peneliti interdisipliner (Vassilakaki et al., 2019). Para professional informasi dalam menjalankan perannya pada preservasi warisan budaya dengan memanfaatkan lokasi pusat budaya dan/atau perpustakaan untuk mempromosikan hasil temuan penelitian mereka sehingga dapat diakses oleh khalayak yang lebih luas. Mereka menggunakan fasilitas dalam perpustakaan untuk melatih khalayak luas tentang bagaimana menggunakan hasil penelitian ini selanjutnya serta melakukan pengembangan terhadap hasil temuan tersebut.

Kendala dalam hal kurangnya kesadaran dari individu dan masyarakat menyebabkan perpustakaan mempunyai kendala atau tantangan paling besar dalam hal kebijakan atau regulasi pihak yang berwenang. Perpustakaan tidak dapat berperan dengan maksimal dalam melestarikan warisan budaya jika masih terkendala oleh kebijakan dari pimpinan sehingga akan berdampak pada kekurangan SDM, anggaran, dan sarana prasarana dalam mendukung pelestarian warisan budaya itu sendiri. Permasalahan yang sama yang dihadapi oleh Negara Nigeria dalam melaksanakan pelestarian warisan budaya adalah dana atau anggaran. Menurut (Ekwelem et al., 2019) dalam penelitiannya mengenai "Preservation of Cultural Heritage: The Strategic Role of the Library and Information Science Professionals in South East Nigeria" ia menemukan bahwa dana menjadi salah satu tantangan paling sulit yang dihadapi perpustakaan di Nigeria dalam melestarikan warisan budaya. Menurutnya dari semua lembaga publik di Nigeria, perpustakaan umum menjadi salah satu lembaga informasi yang paling kurang didanai di Negara tersebut. Dana dibutuhkan untuk melaksanakan pelestarian warisan budaya sekaligus untuk 
memberikan layanan kepada pengguna, sehingga dalam menjalankan peran serta tugasnya perpustakaan di Negara tersebut menyesuaikan dana yang tersedia. Hal ini ditegaskan oleh (Cortez et al., 2014) bahwa setiap perpustakaan perlu didanai secara memadai untuk memastikan pertumbungan dan perkembangan yang berkelanjutan.

Terkait dengan kendala SDM yang juga diperkuat oleh (Bonn et al., 2017) bahwa kendala dalam melaksanakan pelestarian warisan budaya salah satunya kekurangan SDM yang berpengalaman dan terampil. Sehingga baik staff maupun pustakawan harus dilatih dan dididik mengenai pelestarian warisan budaya secara lebih luas karena diakui bahwa hal tersebut merupakan hal yang esensial dari elemen apapun. Menurut (Harvey, 2013), kursus pendidikan pelestarian untuk para professional informasi biasanya ada dalam satu dari tiga jenis yaitu administrasi perpustakaan sebagai kualifikasi professional pertama, kursus opsional sekitar satu semester atau kualifikasi terpisah, misalnya kursus mengenai pelestarian adminitrasi selama satu atau dua tahun. Harvey lebih lanjut berargumen bahwa penting untuk menawarkan keberlanjutan pendidikan bagi professional informasi dalam pelestarian warisan budaya, dan bagi mereka yang memiliki kualifikasi perlu untuk memperbaharui dan mengembangkan pengetahuan yang telah dimiliki. Sehingga, dengan demikian kebijakan dan regulasi pihak berwenang menjadi peranan yang begitu penting untuk mendukung dana dan SDM dalam pelaksanaan pelestarian warisan budaya di perpustakaan.

\section{E. KESIMPULAN}

Perpustakaan sebagai lembaga dokumenter memiliki tugas dan fungsi pokok dalam kegiatan penelitian dan pendidikan bagi penggunanya, tak hanya itu perpustakaan memiiki tugas dalam mengelola semua jenis dokumen baik itu yang bersifat tacit maupun explicit, termasuk dokumen warisan budaya. Pentingnya pelestarian warisan budaya di Indonesia bukan hanya untuk menjaga nilai-nilai tradisional suatu daerah, tetapi identitas diri bangsa Indonesia yang dikenal sangat kaya akan keragaman budaya. Namun pada pelaksanaan peran perpustakaan dalam melestarikan warisan budaya belum maksimal dikarenakan ada kendala paling besar yaitu kebijakan dari pimpinan terkait. Padahal kebijakan ini merupakan regulasi yang sangat penting dalam proses dilaksanakannya pelestarian warisan budaya di suatu lembaga terutama perpustakaan. Hal tersebut ditunjukan pada artikel jurnal lmiah terseleksi yang memiliki kendala paling besar dalam hal kebijakan yang kemudian menyebabkan terbatasnya Sumber Daya Manusia (SDM), anggaran dan sarana prasarana. Sehingga perpustakaan harus memiliki regulasi dan kebijakan yang konkrit guna mendukung dana dan SDM. Jika hal tersebut terpenuhi maka pelaksanaan pelestarian warisan budaya akan berjalan dengan lancar di perpustakaan, mengingat bahwa warisan budaya ini bukanlah sesuatu hal yang bisa dipermainkan, sehingga perlu untuk dipertahankan untuk generasi mendatang. Pelestarian warisan budaya harus dilakukan sebagai upaya pembangunan agar masyarakat tidak mengalami masalah kerugian identitas, erosi budaya, transfer teknologi serta efek yang dihasilkan dari keterbelakangan2tersebut.

Adapun bentuk peranan dalam pelestarian warisan budaya dilakukan sesuai dengan kebutuhan dan jenis dari perpustakaan, pada artikel jurnal ilmiah terseleksi menyebutkan bahwa kegiatan dalam mengedukasi masyarakat merupakan kegiatan yang paling sering dilakukan lalu terdapat kegiatan lain yaitu perawatan bangunan fisik, konservasi naskah kuno dan penambahan koleksi yang bertemakan warisan budaya menjadi bentuk kegiatan terhadap pelestarian warisan budaya yang dilakukan oleh perpustakaan. 


\section{DAFTAR PUSTAKA}

Adrian, C., Abdullah, R., Atan, R., \& Jusoh, Y.Y. (2016). Towards developing strategic assessment model for big data implementation: A systematic literature review., International Journal Advance Software Computer Application, 8-(3), 1115.

Alwasilah, A. C. (2016). Pokoknya Sunda: Interprestasi untuk aksi. Kiblat.

Anggawira, D., \& Mayesti, N. (2020). The Indonesian national scientific repository: A case study of research data sharing. Preservation, Digital Technology \& Culture, 49-(1), 14-25.

Bonn, M., Kendall, L., \& McDonough, J. (2017). Libraries and archives and the preservation of intangible cultural heritage: Defining a research agend, Champaign Journal, 3-(7), 13-14

Cortez, E.M., Dutta, S.K., \& Kazlauskas, E.J. (2014). What library and information professionals can learn from the information technology and project management knowledge areas, Libraries and the Academy, 4-(1),. 131-144.

De Carlo, I. (2019). Peran Perpustakaan Balai Besar Kerajinan dan Batik dalam melestarikan batik. Prosiding Seminar Nasional Batik Industri Kerajinan dan Batik, https://proceeding.batik.go.id/ index.php/SNBK/article/view/26.

Ekwelem, V. O., Okafor, V. N., \& Ukwoma, S. C. (2011). Preservation of cultural heritage: The strategic role of the Library and Information Science professionals in South East Nigeria., Library Philosophy and Practice, 1-(1),. 90-89.

Grazuleviciute, I.(2011). Cultural heritage in the context of sustainable development, Environmental Research Engineering and Management, 37-(3),74-79.

Handayani, P.W. (2017, Agustus). Systematic review dengan PRISMA (Preferred Reporting Items for Systematic Reviews and Meta-Analyses [Presentasi Makalah]. Dalam Workshop Riset Sistem Informasi Fakultas Ilmu Komputer UI, (hlm. 1-3).
Hani, U., Azzadina, I., Sianipar, C. P. M., Setyagung, E. H., \& Ishii, T. (2013). Preserving cultural heritage through creative industry: a Lesson From Saung Angklung Udjo, Procedia Economics and Finance, 4-(2), 193-200.

Harvey, R. (2013). Preservation in libraries: A reader. Topics in Library and Information Studies. Bowker.

Hidayah, N. (2018). Upaya perpustakaan dalam melestarikan khazanah budaya lokal (Studi Kasus Perpustakaan "HAMKA" SD Muhammadiyah Condongcatur). JIPI (Jurnal Ilmu Perpustakaan dan Informasi), 3-(1),.74-84.

Indonesia, P. N. R. (2007). Undang-Undang Republik Indonesia Nomor 43 Tahun 2007 Tentang Perpustakaan. http://digilib.isi.ac.id/2667/1/UU-432007-PERPUSTAKAAN.pdf

Irfaniah, H. (2020). Urgensi pelestarian pengetahuan tradisional dan peluang perpustakaan umum dalam pelestarian pengetahuan tradisional. Jupiter, 17-(1), 10-19.

Lembaga Ilmu Pengetahuan Indonesia. (2016, 24 Mei). 139 Bahasa Daerah di Indonesia Terancam Punah. Kompas. http://lipi.go.id/lipimedia/139-bahasadaerah-di - indonesia-terancampunah/15938.

Kementerian Pendidikan dan Kebudayaan. (2017, 6 September). Selamat Hari Warisan Budaya! Warisan Budaya untuk Generasi Penerus Bangsa. Kompas. https://www.kemdikbud.go.id/main/blog/2 018/04/selamat-hari-warisan-budayawarisan-budaya-untuk-generasi-penerusbangsa.

Rahayu, E. S. R. (2019). Peran perpustakaan dalam menyelamatkan warisan budaya bangsa. Media Pustakawan, 24-(3), 40-49.

Ranjabar, J. (2016). Sistem sosial budaya Indonesia: Suatu pengantar. PT. Ghalia Indonesia

Saputri, P. M. (2018). Peran perpustakaan dalam melestarikan koleksi naskah lontar di Indonesia. Tren Perpustakaan di Era Millenial, 59-(2), 16-19. 
Songjie, L, \& Xinghua, L. (2011). The role of cultural creative industry in the process of the city development: The case of Jingdezhen. Studies in Sociology of Science, 2-(2), 74-78.

Perry, A. \& Hammond, N (2011). Procedures for performing systematic reviews. Keele University.

Triandini, E., Jayanatha, S., Indrawan, A., Putra, G. W., \& Iswara, B. (2019). Metode systematic literature review untuk identifikasi platform dan metode pengembangan sistem informasi di Indonesia. Indonesian Journal of Information Systems, 1-(2), 63-77.

Turner, D.A. (2015). Reconsidering library collections: Comunnity services as documents. Proceedings from the 12th the Annual Meeting of the Document Academy. http://ideaechange.uakron.edu/ docam/vol2/issI/17.
Vassilakaki, E., Giannakopoulos, G., \& Triantafillou, I. (2019)., The role of libraries in managing cultural heritage information. Bowker.

Wirayati, M. A. (2011). Konservasi manuskrip lontar, Visi Pustaka, 13(2), 72-78.

Wohlin, C. P. Runeson, M. Höst, M. C. Ohlsson, B. Regnell \& A. Wesslén. (2012). Experimentation in software engineering., Springer, 20-(4), 546-548.

Yenianti, I. (2018). Tradisi baru perpustakaan dalam perannya sebagai institusi pengetahuan. Pustabiblia. Journal of Library and Information Science, 2(2), 267-276. 


\section{DAFTAR GAMBAR}

\begin{tabular}{|c|c|c|}
\hline Judul Artilkel & Penulis/Jurnal & Kode Artilsel \\
\hline $\begin{array}{c}\text { Upaya Pelestarian Bangunan Cagar } \\
\text { Budaya Perpustakaan Bank Indonesia } \\
\text { Surabaya }\end{array}$ & $\begin{array}{l}\text { Faridha Larashati Dewi Jumal } \\
\text { Antrounair } 53 \text { (2016) dan }\end{array}$ & $\mathrm{Al}$ \\
\hline $\begin{array}{c}\text { Peran Perpustakaan dalam } \\
\text { Menyelamatkan Warisan Budaya } \\
\text { Banga }\end{array}$ & $\begin{array}{l}\text { Endang Sri Rusmiati Rahayu Media } \\
\text { Pustakawan } 243 \text { (2019): } 40-49\end{array}$ & A2 \\
\hline $\begin{array}{c}\text { Peran Perpustakian Balaì Besar. } \\
\text { Rerajinan Dan Batik Dalam } \\
\text { Melestarikan Batik }\end{array}$ & $\begin{array}{l}\text { Tvone De Carlo/ Prosidmg Online } \\
\text { Seminar Nasional Batik dan Kerajiman } \\
\text { Vol 1. No. 1.2019 }\end{array}$ & A3 \\
\hline $\begin{array}{l}\text { Upaya Pelestarian Naskah Kuno Di } \\
\text { Badan Perpustakaan Dan Arsip } \\
\text { Daerah Provinsi Sulawesi Selatan }\end{array}$ & $\begin{array}{l}\text { Hijrana Bahar dan Taufiq Nathar/ } \\
\text { Jumallmu Perpustakaan, Informasi, } \\
\text { dan Kearsipan Khizanah Al-Hikmah, } \\
\text { 3(1).89-100 (2015) }\end{array}$ & A4 \\
\hline $\begin{array}{c}\text { Peranan Perpustakaan Dan Museum } \\
\text { Tembakau Dalam Pelestarian } \\
\text { Kebudayaan Kota Jember }\end{array}$ & $\begin{array}{l}\text { Karina Okta Bella Jumal Kajian } \\
\text { Perpustakaan dan Informasi Voll No } 1 \\
\text { - April } 2017 \text { (42-57) }\end{array}$ & A5 \\
\hline $\begin{array}{l}\text { Upaya Perpustakaan Dalam } \\
\text { Melestarikan Khazanah Budaya Lokal } \\
\text { (Studi Kasus Perpustakcaan "Hamka" } \\
\text { Sd Muhammadiyah Condongcatur) }\end{array}$ & $\begin{array}{l}\text { Nurrohmah Hidayah, SIP/ JPI (Jumal } \\
\text { Ilmu Perpustakaan dan Informasi) Vol. } \\
3 \text { No. } 1 \text { Tahun } 2018\end{array}$ & A6 \\
\hline $\begin{array}{c}\text { Pengelolaan Dokumen Tradisi } \mathrm{T} \text { isan } \\
\text { Gaok sebagai Wujud Pelestarian } \\
\text { Budaya di Perpustakaan }\end{array}$ & $\begin{array}{l}\text { Septa dan Heriyanto/Record and } \\
\text { Library Joumal, 6(1), 89-98 (2020) }\end{array}$ & A? \\
\hline $\begin{array}{l}\text { Pengadaan Kolekifi Xiuatan Lojal.... } \\
\text { "Local Content" "Sebagai Upaya } \\
\text { Pelestarian Budaya Daerah Di Dinas } \\
\text { Kearsipan Dan Perpustakaan Provinsi } \\
\text { Sumatera Barat }\end{array}$ & $\begin{array}{l}\text { Cici Anjelina Putri dan Nurizzati Tlmu } \\
\text { Informasi Perpustakaan dan } \\
\text { Kearsipan } 8.1 \text { (2019):73 }\end{array}$ & As \\
\hline $\begin{array}{l}\text { Peranan Balai Pelestarian Cagar } \\
\text { Budaya (BPCB) Aceh Dalam } \\
\text { Pelestarian Situs-Situs Bersejarah Di } \\
\text { Kota Banda Aceh Tahun 1990-2015 }\end{array}$ & $\begin{array}{l}\text { Dhani Oga Umar, Husnaini dan Teuku } \\
\text { Abdullah JM: Jumal Imiah } \\
\text { Mahasiswa Pendidikan Sejarah } 2.1 \\
\text { (2017). }\end{array}$ & A9 \\
\hline $\begin{array}{c}\text { Peran Perpustakaan Dalam } \\
\text { Melestarikan Koleksi Naskah Lontar } \\
\text { Di Indonesia }\end{array}$ & $\begin{array}{l}\text { Putu Xartina Saputri/ Tren } \\
\text { Perpustakaan Di Era Millenial } 59 \\
(2018)\end{array}$ & Alo \\
\hline $\begin{array}{c}\text { Peran Portal Web Surabaya Memory } \\
\text { Dalam Pelestarian Pusaka Budaya } \\
\text { (Studi Kasus di Library @UK Petra } \\
\text { Surabaya) }\end{array}$ & $\begin{array}{l}\text { Sud Numahma Kuswati dan } \\
\text { Jumino/Jumal Inu Perpustakaan } 63 \\
(2019) \text { : } 81-90 \text {. }\end{array}$ & All \\
\hline $\begin{array}{c}\text { Ketersediaan Kolelksi Local Content } \\
\text { Sebagai Upaya Pelestarian Budaya } \\
\text { Daerah Di Dinas Arsip Dan } \\
\text { Perpustakaan Daerah Kabupaten } \\
\text { Banyumas }\end{array}$ & $\begin{array}{l}\text { Ema Nur Iftitah Ratnaningrum dan } \\
\text { Yanuar Yoga Prasetyawan/Jumal Ilmu } \\
\text { Perpustakaan } 7.4 \text { (2018): } 71-80\end{array}$ & A12 \\
\hline
\end{tabular}

Gambar 1 Hasil Temuan Artikel Jurnal Ilmiah Terseleksi

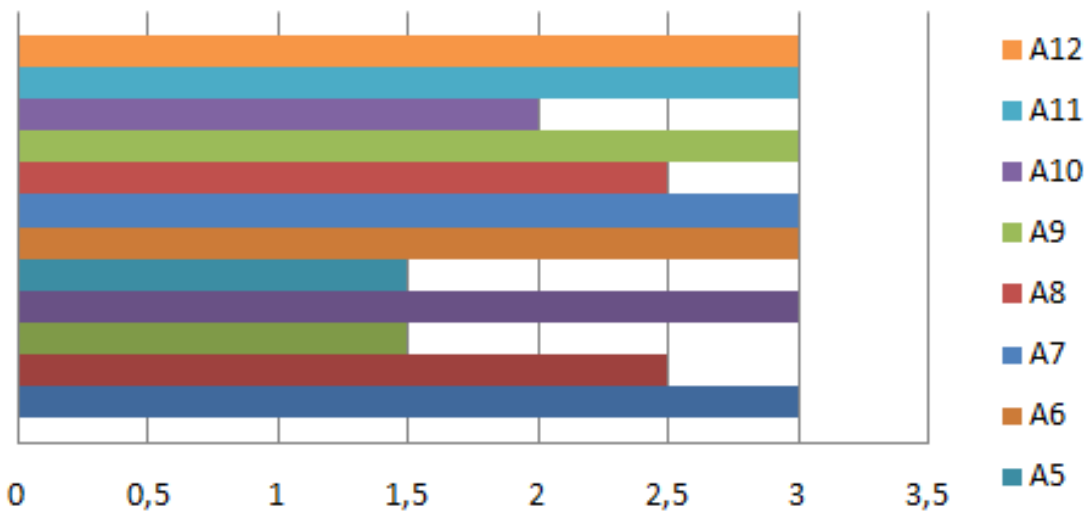

Gambar 2 Penilaian Kualitas Hasil Penelitian 


\section{DAFTAR GAMBAR}

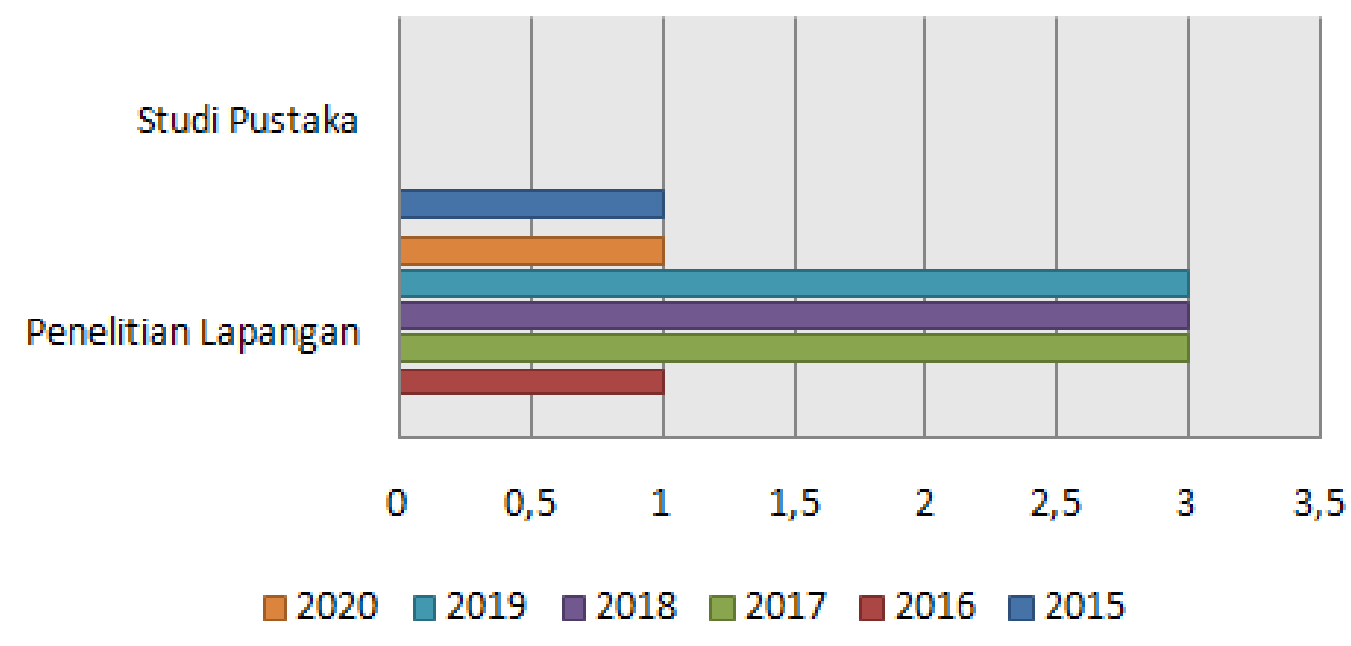

Gambar 3 Pengguna metode dalam artikel

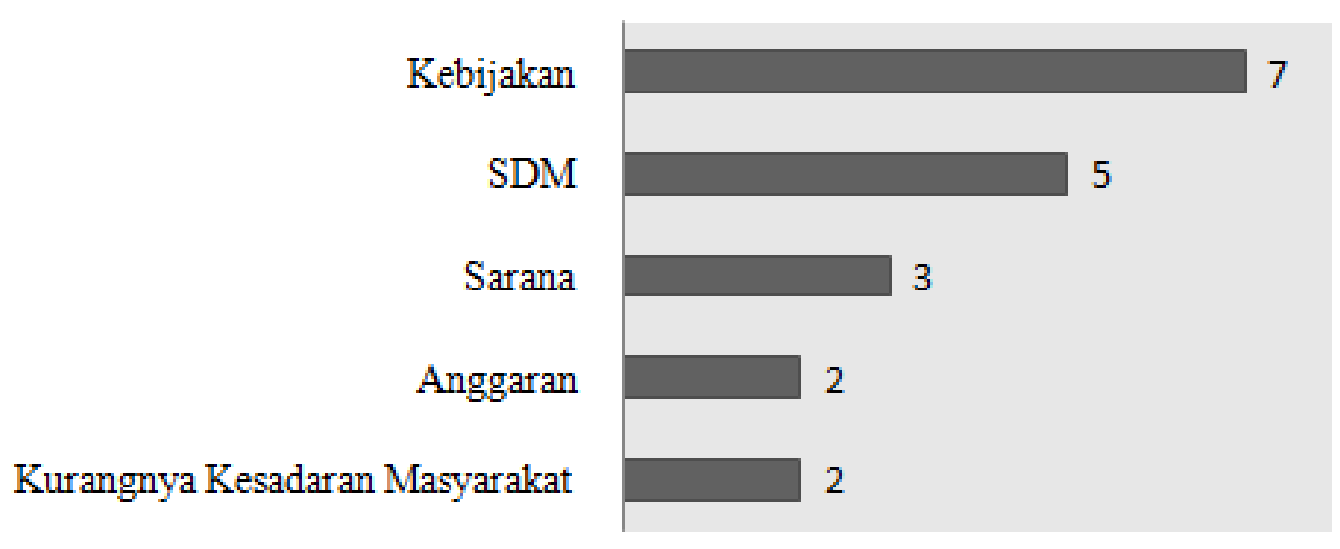

Gambar 4 Kendala dalam Pelestarian Warisan budaya

Mengedukasi Masyarakat Pengguna

Perawatan Bangunan Fisik

Konservasi Naskah Kuno

Penambahan Koleksi

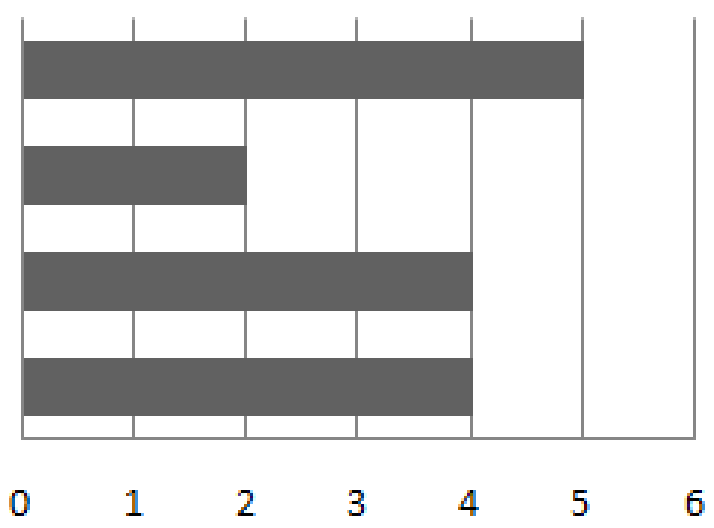

Gambar 5 Bentuk Peranan dalam Pelestarian Warisan budaya 